\title{
INTERNAL SITUATIONS IN COMMUNITY LAW: AN UNCERTAIN SAFEGUARD OF COMPETENCES WITHIN THE INTERNAL MARKET
}

\begin{abstract}
Mislav Mataija*
Summary: This article deals with the so-called internal situation rule, which prevents the application of European Community law in cases deemed to be confined to one Member State. Rather than focus on possible avenues for avoiding the 'reverse discrimination' against the actors of the regulating state (eg its own nationals) which arises because of the non-application of EC law, I assess the costs and benefits of the rule directly. The approach to this problem is, first, to conceptualise the internal situation rule as a specific, substantive requirement of EC provisions that assume cross-border movement, and not as an overarching, general principle of EC law. With this in mind, I go on to claim that the rule is largely inadequate for the purpose of protecting Member State competences. Because the rule focuses on cross-border movement in the abstract sense, it does not clearly delineate an 'internal' sphere that Member States could regulate independently. Next, I analyse how the case law of the European Court of Justice has interpreted the internal situation rule in various areas of free movement law, concluding that the rule is overly formalistic and that it fails to distinguish between cases where there is a true impact on the internal market and those where there is not. In addition, I analyse the disparities in its application, arguing that they cannot be accounted for by the differences between, eg the free movement of goods and the free movement of persons. Finally, I suggest a more substantive approach to defining internal situations, inspired in particular by public procurement and competition case law. Instead of looking for factual cross-border links, I suggest that what should be at stake is the crossborder impact of the restriction (Member State legislation, administrative measure, practice, etc) that is being challenged.
\end{abstract}

\section{Introduction}

Under normal circumstances, a national measure or practice which runs contrary to EC law would have to be put aside on the basis of the supremacy of Community law. ${ }^{1}$ In the internal market context, the Eu-

\footnotetext{
* Mislav Mataija, Assistant, Jean Monnet Department of European Public Law, Faculty of Law, University of Zagreb. The author wishes to thank Professor Katherine Franke and the participants of the Legal Scholarship seminar at Columbia Law School for their invaluable
} 
ropean Court of Justice has used the principles of direct effect and supremacy to condemn a number of laws and practices which created barriers to the free movement of goods, persons, services, establishment and capital. ${ }^{2}$ However, in some cases which are substantially related to only one Member State, according to the case law of the Court, there is no recourse to these provisions. These are, according to the Court, internal situations which fall outside the scope of EC law. Individuals who have not exercised their right to free movement have no redress against their own state or other individuals, because there is no cross-border element.

Much of the scholarly writing on this topic focuses on the issue of the reverse discrimination which results from the application of the internal situation rule. ${ }^{3}$ Because the Community's standard of protection for private persons does not apply in cases confined to one Member State, ${ }^{4}$ that State's economic actors usually end up being treated less favourably than those of other Member States ${ }^{5}$ in a comparable situation. This is

help in developing this paper, as well as to Professors George A Bermann, Petros Mavroidis and Siniša Rodin for their insightful comments. Please direct all comments to mislav. mataija@pravo.hr.

${ }^{1}$ The principle of direct effect enables parties to rely on EU law directly in front of national courts, while the principle of supremacy makes EU law prevail over conflicting national provisions, which have to be put aside. See, among others, B De Witte, 'Direct Effect, Supremacy and the Nature of the Legal Order' in P Craig and G De Búrca (eds), The Evolution of EU Law (1999).

2 Some of the more famous examples are Case 8/74 Procureur du Roi $v$ Benoit and Gustave Dassonville [1974] ECR 847, Case 120/78 Rewe-Zentral AG v Bundesmonopolverwaltung für Branntwein [1979] ECR 649, Case C-55/94 Reinhard Gebhard v Consiglio dell'Ordine degli Avvocati e Procuratori di Milano [1995] ECR I-4165, Case 71/76 Jean Thieffry $v$ Conseil de l'ordre des avocats à la cour de Paris [1977] ECR 765, and Case C-292/89 The Queen $v$ Immigration Appeal Tribunal ex p Gustaff Desiderius Antonissen [1991] ECR I-745.

3 Among others: SD Kon, 'Aspects of Reverse Discrimination in Community Law' (1981) 6 EL Rev 75; A Tryfonidou, 'Reverse Discrimination in Purely Internal Situations: An Incongruity in a Citizens' Europe' (2008) 35 Legal Issues of Economic Integration 43; M Poiares Maduro, 'The Scope of European Remedies: The Case of Purely Internal Situations and Reverse Discrimination', in C Kilpatrick, T Novitz and P Skidmore (eds), The Future of European Remedies (2000); E Cannizzaro, "Producing "Reverse Discrimination" through the Exercise of EC Competences' (1997) Ybk Eur L 29.

4 Reverse discrimination is not sufficient in itself to invoke Community law, as confirmed recently in C-212/06 Gouvernement de la Communauté française and Gouvernement wallon [2008] and C-127/08 Metock and Others v Minister for Justice, Equality and Law Reform [2008] (see also Maduro (n 3) p 122). In his opinion in Carbonati Apuani (Case C-72/03 Carbonati Apuani Srl v Comune di Carrara [2004] ECR I-8027), Advocate General Poiares Maduro tried to extend Community law to internal situations through operation of the general principle of non-discrimination. If, in what he terms 'residual situations', reverse discrimination comes about as a direct result of the application of Community law against national legislation, it should be possible to rely on Community law. Instead of free movement rules, parties should be able to invoke the principle of non-discrimination. The Court, however, has not followed this approach so far.

5 The term 'reverse discrimination' implies that there is something back-to-front in the way discrimination happens. It usually happens that Member States discriminate against na- 
perceived as artificial, unfair and somewhat odd in the context of a single market in which the crossing of borders is not the primary concern.

The main purpose of this article, however, is to take a step back from the discrimination issue and look at the internal situation rule itself. The first step will be to examine the purpose the rule should serve: safeguarding Member State competences while ensuring effective regulation of the internal market. This will also help us understand the nature of the rule. Is it a general principle of EU law that one always has to bear in mind when deciding on the applicability of EU law? Or is it merely a step in the analysis of certain EU provisions which are predicated on movement? This article will argue that the case law of the European Court of Justice does not support the first view, even though the rule is sometimes framed in such a way.

The second step of the analysis will be to examine several ways in which the Court has interpreted the rule in various contexts, relaxing it in favour of the applicability of EC law. What I hope to show is that there are inconsistencies in the way the internal situation rule is interpreted and applied. Many of the exceptions and carve-outs from the rule on internal situations have been crafted for specific cases, but could easily be extended across the board.

Finally, I will attempt to build on these observations to suggest a different approach to identifying a situation as 'internal'. Instead of connecting factors (eg the simple fact of movement between Member States), what should be at stake is the more substantive link of a legal situation with internal market rules. To suggest how such a link could be found, I draw inspiration from the Court's case law on the free movement of goods, public procurement and competition law. This approach would not scrap the rule that some purely internal situations fall outside the scope of Community law. However, it would be more grounded in economic reality. The mere fact that a cross-border element can be dug up from the facts of the case should not suffice to bring the matter within the scope of Community law. The radar should be set not to catch the crossborder elements of disputes but their impact on fundamental freedoms.

The article will proceed in three parts. Part 1 will discuss the nature and scope of the rule on internal situations, and their (limited) impact on Member State regulatory autonomy. Part 2 will outline the different approaches to the scope of internal market regulation adopted by the Court, and highlight inconsistencies. Part 3 will build on Parts 1 and 2

tionals of other Member States. With 'reverse' discrimination they do the opposite. It should be noted, however, that the existing approach to internal situations could allow discrimination against anyone who has not engaged in cross-border movement. These may or may not be the economic actors a Member State might normally be interested in protecting. 
to suggest a unified approach to the question of which situations should be covered by internal market rules. This tentative solution will, however, stop short of addressing the second logical step, which is the issue of reverse discrimination: whether there is a way, within EU law, to remedy the unfavourable treatment suffered by those who are left outside the scope of the rules. ${ }^{6}$

\section{Origins and nature of the internal situation rule}

The history and development of the judge-made concept of internal situations has been explored extensively in the literature. ${ }^{7}$ For the purposes of this article it is only necessary to sketch the main developments.

The first complete statement of the internal situation rule came in the field of the free movement of persons in the Saunders ${ }^{8}$ judgment. The Court stated that the purpose of Article 48 (now 39) EC is to prevent adverse treatment of nationals of other Member States, and that the provisions of the Treaty on freedom of movement for workers cannot ... be applied to situations which are wholly internal to a Member State, in other words, where there is no factor connecting them to any of the situations envisaged by Community law.' In Saunders, this holding seemed to depend on the fact that Member State jurisdiction in criminal law was at stake. ${ }^{10}$ In subsequent cases, however, the rule was applied in contexts that have nothing in common with traditionally sensitive areas, such as criminal law.

The basic statement of the rule seems simple enough. If a dispute does not involve the cross-border exercise of market freedoms, it is normally held to be an internal situation, and Community law does not apply. In its early judgments such as Moser (persons) and Höfner (services), ${ }^{11}$ the Court labelled situations internal even if home country nationals were potentially deterred from exercising their free movement rights. What was required was actual movement, or an actual cross-border element. Later on, the Court relaxed this requirement and made it more complex. ${ }^{12}$

Before examining these developments, however, it is necessary to think about why the rule even exists and how it should be assessed.

\footnotetext{
6 For some well argued proposals, see Maduro and Tryfonidou (n 3).

7 Apart from the works cited in n 3, see NN Shuibhne, 'Free Movement of Persons and the Wholly Internal Rule: Time to Move On?' (2002) 39 CML Rev 731.

8 Case 175/78 The Queen $v$ Vera Ann Saunders [1979] ECR 1129.

9 Saunders (n 8) para 11.

10 Saunders (n 8) para 10. See Shuibhne (n 7) 774-775.

11 Case 180/83 Hans Moser v Land Baden-Württemberg [1984] ECR 2539; Case C-41/90 Klaus Höfner and Fritz Elser v Macrotron GmbH [1991] ECR I-1979.

12 See section 2 for some examples.
} 


\subsection{Underlying values: safeguarding competences and making the internal market effective}

The Treaties set up an elaborate system dividing competences between the Union and its Member States. Instruments such as the principles of conferred powers, subsidiarity and proportionality ${ }^{13}$ are meant to protect Member States from the Community's regulatory overreach.

The internal situation rule has been developed by the European Court of Justice with the same values in mind, attempting to determine the proper scope of the internal market provisions of the EC Treaty and the amount of elbow room they leave to Member States. The case law on internal situations narrows the scope of EC provisions by excluding cases which seem to have little to do with the internal market, allowing Member States to subject these situations entirely to their own law.

At a very general level, this proposition seems legitimate. It cannot be seriously argued that EC rules (or, for that matter, any legal rules) apply to cases which factually do not relate to them. The internal situation rule cannot, however, be assessed only from the point of view of Member State competences. There is something else at the other end of the scale: the unity and effectiveness of the internal market.

Indeed, this is the balance that the Court's internal market case law has sought to strike over the years. The Court has at times stretched the meaning of the EC Treaty's internal market provisions in order to promote the integration of the internal market, ${ }^{14}$ while narrowing it when its impact on Member States' ability to regulate seemed too severe. ${ }^{15}$ The internal situation rule is one of the tools used by the Court to strike this balance by excluding from the analysis those cases which "have no factor linking them with any of the situations governed by Community law and which are confined in all relevant respects within a single Member State'. ${ }^{16}$

\footnotetext{
13 All three principles are covered by Article 5 of the EC Treaty. See also, eg, GA Bermann, 'Taking Subsidiarity Seriously: Federalism in the European Community and the United States' (1994) 2 Colum L Rev 331; A Dashwood, 'The Relationship Between the Member States and the European Union/European Community' (2004) CMLR 355; G Davies, 'Subsidiarity: the Wrong Idea, in the Wrong Place, at the Wrong Time' (2006) CML Rev 63.

14 The judgments in Case 8/74 Procureur du Roi v Benoit and Gustave Dassonville [1974] ECR 847 and Case 120/78 Rewe-Zentral AG v Bundesmonopolverwaltung für Branntwein [1979] ECR 649 are the most often cited examples.

15 Famously, the Court's carve-out of 'certain selling arrangements' from the application of Article 28 EC in Joined cases C-267/91 and C-268/91 Criminal proceedings against Bernard Keck and Daniel Mithouard [1993] ECR I-6097 para 16 can be seen in this light.

16 Joined cases C-95/99 to C-98/99 and C-180/99 Mervett Khalil (C-95/99), Issa Chaaban (C-96/99) and Hassan Osseili (C-97/99) v Bundesanstalt für Arbeit and Mohamad Nasser (C-98/99) v Landeshauptstadt Stuttgart and Meriem Addou (C-180/99) v Land NordrheinWestfalen [2001] ECR I-7413 para 69.
} 
This wording, repeated in almost all cases invoking the internal situation rule, clearly leaves room for questions. What confines a case to a single Member State, and which elements are relevant in this respect? Does the fact that a case is confined within a Member State suffice, or can there still be certain 'factors' which can bring even internal cases within the scope of Community law? ${ }^{17}$ If the latter is true, what kind of factors?

An attempt to answer these questions must use as a benchmark the competing values of integration of the internal market and the regulatory autonomy of the Member States. How does the internal situation rule advance these two interests?

\subsection{A general principle or a specific substantive requirement?}

Certainly, Member States have a legitimate interest in removing certain cases from the application of Community law. The question is, however, not only which cases can be removed, but also: how useful is the internal situation rule, as devised by the Court, in protecting this legitimate interest in the first place?

To answer this question, it is first necessary to consider the nature of the rule. Is it so general that a 'connecting factor' must be found in all cases where Community law could be invoked, or does it only arise because of the substantive content of certain Community provisions? More specifically, is it true that Community law does not apply whenever a case is confined to one Member State?

The non-applicability of Community law to situations confined within one Member State, with no 'foreign' or 'cross-border' elements, is sometimes understood as a general proposition of EU law. Eleftheriadis, for example, argues that the public law of the EU, as a whole, 'does not apply to purely internal situations according to the allocation of competences determined by the treaties'. ${ }^{18}$ Advocate General Tizzano has termed this a 'principle according to which Community law does not apply to situations in which the key elements are purely internal to a Member State'. ${ }^{19}$

There are more nuanced approaches as well. Maduro has argued that there are two variables which bring a situation within the scope of

\footnotetext{
17 AG Sharpston in Case C-212/06 Government of Communauté française and Gouvernement wallon $v$ Gouvernement flamand, nyr (28 June 2007), paras 134-136, seems to understand these as two separate requirements which need to be fulfilled cumulatively in order for a purely internal case to fall outside the scope of Community law.

18 P Eleftheriadis, 'The Idea of a European Constitution' (2007) 27 OJLS 1, 15.

19 Opinion of Advocate General Tizzano in Case C-209/01 Theodor Schilling and Angelica Fleck-Schilling v Finanzamt Nürnberg-Süd [2003] ECR I-13389 para 83.
} 
Community law: the degree of legal integration and the existence of a cross-border element. ${ }^{20}$ If the depth of integration is sufficiently great, such as in gender discrimination law, there is no further discussion of internal situations. If this is not the case, cross-border elements will be decisive. While noting some areas in which cross-border elements are not decisive, this approach also views the internal situation rule as implicit in all cases where Community law might be applied. ${ }^{21}$

On the other hand, it is also possible to link the internal situation rule only to those provisions of Community law which imply some sort of cross-border element, or at least some impact on cross-border trade. Rather than being an overarching principle of Community law, this view would suggest the rule is no more than an element in the analysis of Treaty free-movement rules and secondary legislation implementing them. Such a conclusion is based on two points.

First, the general nature of the rule is disproved by its complete, not entirely explained, absence from areas such as gender discrimination and product liability. Second, it is not necessary to construe the rule in a general way, because its importance in preserving Member State regulatory autonomy is limited.

\subsubsection{Areas where the rule is not applied}

The fact that there is no overarching principle exempting internal situations from the scope of Community law is apparent from areas where the distinction between internal and external situations could be drawn, but is not.

\subsubsection{Gender discrimination}

An often discussed example is gender equality law, where one could easily imagine 'internal situations'. Nowhere in the Court's numerous judgments is a cross-border element discussed. A worker can claim his or her Community law right to equal pay, fair working conditions or access to employment, even in a completely internal situation (even if both the worker and the employer are confined to a single Member State in all their relevant activities). ${ }^{22}$

\footnotetext{
20 Maduro (n 3) 120-123.

21 See also Shuibhne (n 7) 750.

22 Some examples are Case 222/84 Marguerite Johnston $v$ Chief Constable of the Royal Ulster Constabulary [1986] ECR 1651, Case 170/84 Bilka-Kaufhaus GmbH v Karin Weber von Hartz [1986] ECR 1607, and Case 109/88 Handels-og Kontorfunktionžrernes Forbund I Danmark $v$ Dansk Arbejdsgiverforening acting on behalf of Danfoss [1989] ECR 3199.
} 
This could be explained by any number of differences between gender equality law and free movement law, including the fact that the former is not primarily economic in nature. Still, a clear line between the two fields is difficult to draw. Firstly, an economic rationale was used for the first explicit Treaty provision on gender equality and the Court has spoken of the dual nature of equality - social and economic. ${ }^{23}$ Therefore, notions of cross-border competition are inherent to matters of equality as well, and not only to free movement cases. ${ }^{24}$ Secondly, the Court has justified the direct effect of Article $39 \mathrm{EC}$ (relating to the free movement of persons) on similar grounds to that of Article $141 \mathrm{EC}$ (relating to gender equality). ${ }^{25}$ Thirdly, cases of discrimination against workers argued in the context of Article 39, which clearly imply an internal situation rule, can be distinguished from gender cases only on the grounds of discrimination. ${ }^{26}$ It seems odd that workers mistreated on the basis of gender are preferred to victims of nationality-based discrimination.

However, the internal situation argument is not raised in gender discrimination cases. The question is why, if there is truly a "principle according to which Community law does not apply to situations in which the key elements are purely internal to a Member State'?27

The most plausible answer is simply that neither Article 141 EC nor secondary law adopted on its basis require a cross-border element in order to apply. It follows that the internal situation rule has roots in the substantive content of free movement provisions, not in the general

23 Case 43/75 Gabrielle Defrenne v Société anonyme belge de navigation aérienne Sabena [1976] ECR 455 paras 9-12.

24 Another difference between non-discrimination and free movement provisions of the EC Treaty is that the former have traditionally been viewed as directly effective in disputes between individuals (so-called 'horizontal direct effect') whereas the latter were seen as justiciable only against the state (vertical direct effect). However, all of the free movement provisions have been declared directly effective between individuals in certain circumstances (among others, see Case C-415/93 Union royale belge des sociétés de football association ASBL v Jean-Marc Bosman, Royal club liégeois SA v Jean-Marc Bosman and others and Union des associations européennes de football (UEFA) $v$ Jean-Marc Bosman [1995] ECR I-4921; Case C-281/98 Roman Angonese v Cassa di Risparmio di Bolzano SpA [2000] ECR I-4139; Case C-438/05 International Transport Workers' Federation and Finnish Seamen's Union $v$ Viking Line ABP and OÜ Viking Line Eesti [2007] ECR I-10779; and Case C-341/05 Laval un Partneri Ltd $v$ Svenska Byggnadsarbetareförbundet, Svenska Byggnadsarbetareförbundets avdelning 1, Byggettan and Svenska Elektrikerförbundet [2007] ECR I-11767) except free movement of goods (although even here actions of individuals can be challenged because of the state's failure to prevent them, as in Case C-265/95 Commission v France [1997] ECR I-6959).

25 Shuibhne (n 7) 735.

26 Case C-237/94 John O'Flynn v Adjudication Officer [1996] ECR I-2617 para 18 is an example of a case on migrant workers which extensively uses the legal vocabulary of discrimination.

27 See $n 18$. 
principles of Community law. This conclusion is also supported by the Court's case law on product liability and the common organisation of markets.

\subsubsection{The question of harmonisation}

If an area is harmonised at the European level, again there does not seem to be room for invoking the internal situation argument. An example is product liability, regulated by Directive $85 / 374 .{ }^{28}$ In cases such as González Sánchez and Veedfald, ${ }^{29}$ the disputes did not seem to involve any cross-border element, as they were between private economic actors located within one Member State. ${ }^{30}$ Nevertheless, the Court applied the Directive. Why is the internal situation argument never made?

One answer is that the Directive is one of complete harmonisation, having been adopted under (now) Article 94 EC, which 'provides no possibility for the Member States to maintain or establish provisions departing from Community harmonizing measures'. ${ }^{31}$ If a field is completely harmonised, Member States cannot adopt divergent measures, less or more stringent for producers, granting fewer or more rights. This is presumably why Community law applies to internal situations as well.

Is this convincing? Just because the hands of Member States are tied in situations falling under the scope of a directive, it does not mean that purely internal situations have to be caught by the directive. Therefore, one might imagine a cross-border requirement being pinned on cases such as Gonzalez Sanchez as well. But here, just as in cases of gender discrimination, the argument does not come up.

Moreover, even harmonisation under Article 95 EC (requiring a less stringent procedure than Article 94 EC) seems to exclude the internal situation argument. This was confirmed by the Court, in the context of the Data Protection Directive, ${ }^{32}$ in Rundfunk and Lindqvist. According to

\footnotetext{
28 Council Directive 85/374/EEC [1985] OJ L 210.

29 Case C-183/00 María Victoria González Sánchez v Medicina Asturiana SA [2003] ECR II135 and Case C-203/99 Henning Veedfald $v$ Århus Amtskommune [2001] ECR I-3569. See also Case C-402/03 Skov Žg v Bilka Lavprisvarehus A/S [2006] ECR I-199.

30 In Veedfald, the Directive's rules on product liability were applied to the following facts: a Danish man was to receive a kidney transplant from a public (and publicly-funded) hospital in Denmark, for which he paid no remuneration. The operation was unsuccessful because a defective fluid, produced by another public hospital in Denmark, was used to treat the kidney. Clearly, there is no cross-border movement, and arguably no effect whatsoever on the internal market.

31 González Sánchez (n 29) para 23.

32 Directive 95/46/EC of the European Parliament and of the Council on the protection of individuals with regard to the processing of personal data and on the free movement of such data [1995] OJ L281.
} 
the Court, showing a link to free movement is not necessary in individual cases arising under Article 95 measures, because this could 'make the limits of the field of application of the directive particularly unsure and uncertain, which would be contrary to its essential objective of approximating the laws, regulations and administrative provisions of the Member States'. ${ }^{33}$ In light of all the uncertainties and inconsistencies inherent in the internal situation rule, one might ask if the limits of application of Community law are any less uncertain in cases arising under the Treaty rather than Article 95 harmonisation measures? Why does positive integration (ie harmonisation) automatically apply to situations that negative integration (ie the removal of restrictive Member State measures) cannot reach?

Another area in which there is no mention of the internal situation rule is the common market organisation for various agricultural products. ${ }^{34}$ The Common Agricultural Policy is meant to 'ensure conditions for trade within the Community similar to those existing in a national market' (Article 37(3) EC). This requires its extension to all producers, regardless of any cross-border element. Again, cross border competition is implicit, but the internal situation argument does not appear in specific cases before the Court. ${ }^{35}$

\subsubsection{Interim conclusion}

Clearly, there are at least four articles in the EC Treaty (Articles $37,94,95,141)^{36}$ which allow the EC to regulate internal situations. ${ }^{37}$ This seems proof enough that the internal situation rule is not a general, structural requirement necessary to invoke EU law. It is merely a requirement linked to the content of only those EC provisions that involve a cross-border element. Thus, when the argument is made that a situ-

33 Case C-101/01 Criminal proceedings against Bodil Lindqvist [2003] ECR I-12971 paras 40-41; Joined Cases C-465/00, C-138/01 and C-139/01 Österreichischer Rundfunk and Others [2003] ECR I-4989 paras 41-42.

34 Maduro (n 20).

35 For a recent example, see Case C-208/01 Isabel Parras Medina and Adelina Parras Medina $v$ Consejería de Agricultura y Medio Ambiente de la Junta de Comunidades de CastillaLa Mancha [2002] ECR I-8955.

36 Regarding common market organisation, approximation of laws and the equal treatment of men and women respectively.

37 One could go even further and point to examples such as political rights linked to Union citizenship, eg petitioning the European Parliament or participating in local elections in a place of residence, granted directly by the Treaty (arts 19-21 EC). Clearly, Member States would be in direct violation of the Treaty were they to obstruct these rights to any Union citizen, and the internal situation argument would not be helpful. This paper, however, focuses on areas that can be compared more directly with those in which the internal situation rule does appear. 
ation falls outside the scope of EU law, it is because of the substantive content of the rule in question, and not because of a general principle of Community law.

\subsection{The internal situation rule and Member State competences}

The internal situation rule is generally viewed as a safeguard of Member State competences. According to Ritter, 'it makes sense for the Member States to retain competence over their purely internal sphere - if only because they may wish to regulate their respective societies on the basis of policy goals other than the narrow list of public order objectives set out in the Treaty'. ${ }^{38}$

While the general sentiment is hard to criticise, when one gets down to the nuts and bolts of it, this idea becomes questionable. In order for the internal situation rule to genuinely protect Member State competences, one would need to define a clear class of subject matter or persons which the Member States could regulate exclusively (their "purely internal sphere', as Ritter terms it). The definition of internal situations, however, does not allow this.

The problem is that none of the factors which link a specific case to one and only one Member State, not even nationality or place of establishment, suffices in itself to make a situation internal. Rather, it is the actual or possible exercise of market freedoms that triggers the application of Community law. What the Court seems to focus on, therefore, are not so much the parties or the dispute, but movement itself in the abstract sense.

Consequently, Member States are not free to treat, eg, their nationals or residents in any way they want, escaping liability under EU law. It is clear that individuals can claim rights arising from their status as EU citizens, ${ }^{39}$ or the right of establishment (as long as they are in a situation 'equivalent to that of any other person enjoying the rights and liberties guaranteed by the Treaty'), ${ }^{40}$ even against their Member State of origin.

38 C Ritter, 'Purely Internal Situations, Reverse Discrimination, Guimont, Dzodzi and Article 234' (2006) 31 EL Rev 690, 701.

39 Joined cases C-11/06 and C-12/06 Rhiannon Morgan v Bezirksregierung Köln (C-11/06) and Iris Bucher $v$ Landrat des Kreises Düren (C-12/06) [2007] ECR I-9161 para 22; Case C192/05 Tas-Hagen and Tas [2006] ECR I-10451 para 19. For a different view, see S Besson and A Utzinger, 'Introduction: Future Challenges of European Citizenship - Facing a WideOpen Pandora's Box' (2007) 13 Eur LJ 573, 583.

40 Case C-107/94 PH Asscher v Staatssecretaris van Financiën [1996] ECR I-3089 para 32, Case C-60/00 Mary Carpenter $v$ Secretary of State for the Home Department [2002] ECR I-6279 para 23. 
Even though the Court made such a statement as early as in Knoors, ${ }^{41}$ confusion sometimes remains. A good example is 3 Glocken. ${ }^{42}$ In this case, the Court proclaimed Italian legislation restricting the marketing of pasta contrary to Article 28 EC. In an obiter dictum, however, the Court stated that Italy is still free to impose the legislation on pasta manufacturers 'established in Italy.'43 In the more recent case of Granarolo, AG Léger proposed a similar solution, saying that the legislation is contrary to EC law only with respect to foreign producers or goods produced abroad, and not to producers established in Italy or goods produced in Italy. ${ }^{44}$

There are serious difficulties with this line of reasoning. First of all, the significance of place of establishment is questionable. Even if a company is established in Italy, it might still for example be producing goods elsewhere and exporting them to Italy. Place of establishment is not determinative of the 'internal' status of a situation: rather, what counts is the occurrence of (or the potential for) movement in a particular case. A regulatory requirement can only be imposed on cases of, eg pasta produced in Italy by an Italian company, and sold only on the Italian market. ${ }^{45}$ Of course, if the Community issue expressly turns on nationality as such, nationality could possibly keep the case outside the scope of Community law. ${ }^{46}$ But this is only the result of the specific substantive content of the rule which is questioned.

In addition, the internal situation rule is not effective in reserving a sphere of sovereignty that Member States can rely on. It is only possible for them to adopt legislation excluding situations where it is clear that there is no cross-border element whatsoever. Engineering such a provision can be a difficult, if not impossible task. ${ }^{47}$

\footnotetext{
${ }^{41}$ Case 115/78 J Knoors $v$ Staatssecretaris van Economische Zaken [1979] ECR 399.

42 Case 407/85 3 Glocken GmbH and Gertraud Kritzinger v USL Centro-Sud and Provincia autonoma di Bolzano [1988] ECR 4233.

433 Glocken (n 42) para 25.

44 Opinion of AG Léger in Case C-294/01 Granarolo SpA v Comune di Bologna [2003] ECR I-13429 para 82. Interestingly, the Court in the same case did not use the internal situation argument at all, simply saying that the national legislation is contrary to Article 28.

${ }^{45}$ Even then, one could say that there might be a cross-border element. What if pre-processed milk (in a case such as Granarolo) is acquired, as an input, from farmers from other Member States? In that case, a regulatory requirement on the final product would reduce market access for the input - in this case, milk.

46 This might have been the case in Case C-127/08 Blaise Baheten Metock and Others $v$ Minister for Justice, Equality and Law Reform, nyr (25 July 2008), had the applicants' spouses been Irish nationals, since the Directive explicitly gave rights only to nationals of other Member States.
}

47 Shuibhne (n 7) in n 42. 
Because the internal situation rule focuses simply on movement in the abstract sense, it does not aid the preservation of Member State competences even where those competences are exclusive. A good example is the judgment in Tas-Hagen. ${ }^{48}$ Not only were the applicants Dutch citizens, but the Court held that the legislation they challenged (granting a benefit to civilian war victims) falls within exclusive Member State competence. Neither of these two factors, however, served to make the case 'purely internal', simply because there was some cross-border element (the applicants were denied the benefit as a result of moving to Spain). ${ }^{49}$

This example shows that the policy space left to Member States thanks to the internal situation rule is only vaguely related to the protection of their competences. Member States are not allowed to reserve - as such - certain classes of persons or production factors they might have an interest in regulating (eg citizens, residents, products). They can merely carve out specific situations in which no cross-border element exists, depending on the content of the EU provisions. To avoid the application of EC law in Tas-Hagen, the Netherlands would have had to predict all the situations where somebody's exercise of free movement might make them worse off in the context of Dutch law, and provide for a different legal regime for them. Even if such legislative distinctions can be drafted, because of their factually contingent, even arbitrary nature, they do not effectively protect Member State competences. ${ }^{50}$

\section{Internal situations and free movement}

After looking at the internal situation rule from the point of view of Member State competences, it remains to be seen what its costs and benefits are for internal market regulation.

As far as the internal market is concerned, the measure of success of the internal situation rule should be how well it distinguishes between cases where there is an adverse impact on trade which Community law should prohibit, and cases where trade is only marginally affected and the disputed measure or activity can be tolerated. The case law does not perform this task well either.

48 Case C-192/05 K Tas-Hagen and R.A Tas v Raadskamer WUBO van de Pensioen-en Uitkeringsraad [2006] ECR I-10451.

49 Most recently, in Case C-40/05 Kaj Lyyski v Umeå universitet [2007] ECR I-99, it was confirmed that Member States lose exclusive competence over their nationals or residents as soon as they exercise one of the fundamental freedoms: 'any Community national who, irrespective of his place of residence and his nationality, has exercised that right ... falls within the scope of that article' (para 30).

50 The ease of using such a measure again depends on the specific nature of the Community measure. If, for example, a directive itself applies only to nationals of other Member States, the line could be easily drawn by the legislator. This, however, only reinforces the nature of the internal situation rule. 
As others have pointed out, in the context of a single internal market, defined by Article 14(2) EC as 'an area without internal frontiers in which the free movement of goods, persons, services and capital is ensured', the application of Community law should not simply depend upon the crossing of borders. ${ }^{51}$ One could easily imagine cases where the cross-border requirement is fulfilled, but which still do not call for the application of Community law, and vice versa.

In addition, the Court's case law has been less than consistent on what constitutes an internal situation and what does not. The only thing that can be concluded with some certainty is that some sort of cross-border element needs to be found in order to apply free movement rules. This, however, as pointed out by Pickup, ${ }^{52}$ only begs the question: who has to move and when? It is not clear which elements can be taken into account and which of them will suffice. Moreover, the Court's interpretation varies according to the legal provision, so that the definition of internal cases in the areas of free movement of persons, goods etc is not uniform.

I will proceed by examining the Court's approach to defining the internal situation rule. This case law, which has generally made it easier to invoke Community law, can be broadly divided into two groups. The first group brings a greater number of situations under the umbrella of Community law by finding a cross-border element with relative ease. The second group goes a step further by extending Community law even to seemingly internal cases, where the disputed measure or activity as such has cross-border implications.

\subsection{Extending the links with cross-border movement}

2.1.1 Free movement of persons - relaxing the 'who' and 'when' of movement

Free movement of persons is an area in which the nature of the 'links' necessary for the situation to come under the scope of Community law has become increasingly complex. ${ }^{53}$ Even though some movement is normally required in order to fall under the scope of Article 39 EC (regarding the free movement of workers) or provisions of secondary law, it is not necessary for the case to arise directly out of any actual cross-border movement of the parties. In fact, the cross-border movement that is required may be only very indirectly linked to the case at hand.

51 AG Sharpston in C-212/06 (n 17) para 116.

52 DMW Pickup, 'Reverse Discrimination and Freedom of Movement for Workers' (1986) 23 CML Rev 135, 156.

53 The case law has been explored in more detail elsewhere. See eg Shuibhne (n 7), Pickup (n 52), Tryfonidou (n 3). 
Firstly, the movement could have happened in the past. If a person had previously used the right to free movement, the situation falls under Community law. Thus, migrant workers are granted certain rights even after the end of their employment relationship. ${ }^{54}$

Secondly, even if the movement was not directly linked to the case at hand, and the situation is otherwise internal, the cross-border requirement is fulfilled as long as the exercise of movement puts a party at a disadvantage. ${ }^{55}$

Thirdly, one persons' exercise of cross-border movement can fulfil the requirement of movement for someone else - usually a family member. In Schempp, the fact that the applicant's ex-wife had moved to Spain triggered the application of Articles 12 and $18 \mathrm{EC},{ }^{56}$ because it adversely affected the applicant's right to deduct the maintenance payments he paid to her in his tax returns.

Fourthly, sometimes the cross-border criterion does not have to involve any movement at all, at least not in the literal sense. In Commission $v$ Spain (C-286/06), ${ }^{57}$ a Spaniard was able to rely on EC law against the Spanish administration in order to seek recognition of a professional degree, even though he studied in Spain. What made the situation 'external' was the fact that an Italian university had issued the diploma, and the applicant was therefore entitled to work in Italy. In Zhu and Chen, the Court held that the mother of a child born in Northern Ireland is able to rely on EC law on her daughter's behalf in front of courts in the United Kingdom, solely on the basis of the daughter's Irish nationality (acquired thanks to the ius soli principle), despite the fact that neither of them had actually moved between two Member States. ${ }^{58}$

Finally, sometimes the mere fact that a national measure deterred a person from exercising free movement rights will suffice to fulfil the cross-border requirement. Some of these judgments will be reviewed below in more detail, since they are the strongest example of the Court's willingness to interpret the internal situation rule widely.

\footnotetext{
54 See eg the judgment in Case C-57/96 H Meints $v$ Minister van Landbouw, Natuurbeheer en Visserij [1997] ECR I-6689 para 40; Shuibhne (n 7) 743.

55 Joined cases C-11/06 and C-12/06 Rhiannon Morgan v Bezirksregierung Köln (C-11/06) and Iris Bucher v Landrat des Kreises Düren (C-12/06) [2007] ECR I-9161 para 25. See also Case C-406/04 De Cuyper [2006] ECR I-6947 para 39 and Case C-192/05 K Tas-Hagen and RA Tas $v$ Raadskamer WUBO van de Pensioen-en Uitkeringsraad [2006] ECR I-10451 para 31.

56 Case C-403/03 Egon Schempp v Finanzamt München V [2005] ECR I-6421 paras 22-25.

57 Case C-286/06 Commission $v$ Spain, nyr (23 October 2008), para 67.

58 Case C-200/02 Kunqian Catherine Zhu and Man Lavette Chen $v$ Secretary of State for the Home Department [2004] ECR I-9925 para 19.
} 


\subsubsection{The criterion of deterrence}

Cases dealing with free movement of persons usually involve more than purely economic considerations, as personal relationships and family life can be affected. Appealing to Community rights of movement is often the only choice for people facing deportation or separation from their families. Therefore, Community law arguments tend to come up quite frequently even in seemingly internal cases.

The Court could have attempted to apply Community law in 'internal' cases by appealing directly to fundamental rights, such as those enshrined in the European Convention on Human Rights, or to the general principle of non-discrimination. Instead, the case law has relied heavily on a rather wide interpretation of cross-border elements.

In Singh, ${ }^{59}$ an Indian claiming the right of residence in the UK came within the scope of Articles 39 (free movement of persons) and $43 \mathrm{EC}$ (establishment of self-employed persons). His wife, a UK national, had previously worked in other Member States, and he had accompanied her there. According to the Court, allowing the UK to deny him the right of residence would deter his wife from exercising her free movement rights. This was enough to fulfil the cross-border requirement. ${ }^{60}$

However, the link between Mrs Singh's previous work abroad and her husband's later right of residence in the UK is less than clear. It is hard to see how Mrs Singh was deterred from moving abroad when the rights of Mr and Mrs Singh were, strictly speaking, not affected by their exercise of cross-border movement. ${ }^{61}$ A similar approach, raising similar difficulties, was applied again quite recently in Eind. ${ }^{62}$

59 Case C-370/90 The Queen $v$ Immigration Appeal Tribunal et Surinder Singh ex $p$ Secretary of State for Home Department [1992] ECR I-4265. On Singh, see RCA White 'A Fresh Look at Reverse Discrimination' (1993) 18 EL Rev 527.

$60 \mathrm{Mr}$ Singh's movement from India to the UK, according to previous judgments, would not have been relevant. See Joined cases 35 and 36/82 Elestina Esselina Christina Morson $v$ State of the Netherlands and Head of the Plaatselijke Politie within the meaning of the Vreemdelingenwet; Sweradjie Jhanjan $v$ State of the Netherlands [1982] ECR 3723 paras 15-17.

61 See Maduro (n 3) 124-125. This problem arose several years later in Akrich (Case C109/01 Secretary of State for the Home Department $v$ Hacene Akrich [2003] ECR I-9607). In this case, the Court held that there is no deterrence to movement if the spouse, who is not an EU citizen, had no residence rights prior to moving to another Member State, under Article 10 of Regulation No 1612/68 (paras 52-54). However, quite recently, in Metock (n 4) the Court explicitly reconsidered this view, stating: 'The refusal of the host Member State to grant rights of entry and residence to the family members of a Union citizen is such as to discourage that citizen from moving to or residing in that Member State, even if his family members are not already lawfully resident in the territory of another Member State' (para $64)$.

62 Case C-291/05 Minister voor Vreemdelingenzaken en Integratie $v$ RNG Eind [2007] ECR I-10719. In this case, an underage daughter, a third country national, was held to have a 
The stretching of the criteria went even further in Carpenter, ${ }^{63}$ where a Philippine national fought a deportation order by invoking her husband's right to provide services. The Court accepted this argument:

It is clear that the separation of Mr. and Mrs. Carpenter would be detrimental to their family life and, therefore, to the conditions under which Mr. Carpenter exercises a fundamental freedom. That freedom could not be fully effective if Mr. Carpenter were to be deterred from exercising it by obstacles raised in his country of origin to the entry and residence of his spouse. ${ }^{64}$

The case turned on the economic cross-border link necessary to invoke Article 49, even if the Court went on to examine the UK's justification in trying to deport Mrs Carpenter in light of the fundamental right to family life (citing Article 8 of the European Convention on Human Rights). ${ }^{65}$

There are two difficulties with the Court's liberal approach to finding a cross-border element in cases such as Singh and Carpenter. First, by using the provision of services or employment in another Member State as the predominant criteria, the Court adopts an indirect and secondbest solution to what is actually at stake: the right to family life. This emphasises what has been termed the 'instrumental' nature of human rights protection within the context of internal market law. ${ }^{66}$

Second, were the Court to apply the same standard consistently, especially outside of the context of free movement of persons, there would be far-reaching consequences. The implications of Carpenter are particularly important, because of the ease with which a cross-border element is found in the provision of services. ${ }^{67}$ As outlined by AG Léger in Wouters:

right to join her father in his Member State of origin even though she had no right to reside there under national law, and even though her father was not engaged in any economic activity there (but had been working in another Member State previously). Again, the Court relied on deterrence as the reason for applying Community law. This deterrence would come about 'simply from the prospect, for that same national, of not being able, on returning to his Member State of origin, to continue living together with close relatives, a way of life which may have come into being in the host Member State as a result of marriage or family reunification' (para 36).

63 Carpenter (n 40). See also A Tryfonidou, 'Mary Carpenter v Secretary of State for the Home Department: The Beginning of a New Era in the European Union' (2003) 14 King's College Law Journal 81.

64 Carpenter (n 40) para 39.

65 Carpenter (n 40) para 41. See also X Groussot, 'UK Immigration Law Under Attack and the Direct Application of Article 8 ECHR by the ECJ' (2003) 3 Non-state Actors and International Law 187.

66 Tryfonidou (n 3) 61.

${ }^{67}$ This is far from saying that internal situations do not exist in the area of free provision of services. See eg Case C-97/98 Peter Jägerskiöld $v$ Torolf Gustafsson [1999] ECR I-7319 paras 42-43 and Joined cases C-317/01 and C-369/01 Eran Abatay and Others (C-317/01) 
'there is no need for the provider or recipient of services to move within the Community. The link to Community law may be found in the mere movement of the service concerned'. ${ }^{68}$ Moreover, there is also a right to receive services, either from across a border (eg by watching television or using online services) or by travelling abroad (eg as a tourist) ${ }^{69}$ It is hard to imagine a person living in an EU Member State who does not at least occasionally receive a cross-border service. ${ }^{70}$ Were the Court to extend Carpenter to recipients of services, almost anyone (and their spouse) could fulfil the cross-border requirement and challenge any number of national laws and practices as a matter of Community law.

\subsubsection{Citizenship of the EU - high hopes, little effect}

Citizenship of the EU, introduced by the Treaty of Maastricht and accorded great importance by a series of judgments, has been used repeatedly as an argument in favour of removing the internal situation rule completely and putting an end to reverse discrimination . The Court's holding in Grzelczyk that 'Union citizenship is destined to be the fundamental status of nationals of the Member States, enabling those who find themselves in the same situation to enjoy the same treatment in law irrespective of their nationality, ${ }^{71}$ made the cross-border requirement seem almost redundant.

EU citizenship is important because the movement rights it grants are not tied only to work or economic activity. ${ }^{72}$ On this basis, it has been argued that 'the requirement that someone must leave their Member State in order to trigger the advantages of Community law, viewed against strenuous Community promotion of common citizenship bonds, seems ... to make less sense than ever. ${ }^{73}$

and Nadi Sahin (C-369/01) v Bundesanstalt für Arbeit [2003] ECR 12301 paras 107-108.

68 Opinion of AG Léger in Case C-309/99 JCJ Wouters, JW Savelbergh and Price Waterhouse Belastingadviseurs BV v Algemene Raad van de Nederlandse Orde van Advocaten, intervener: Raad van de Balies van de Europese Gemeenschap [2002] ECR I-1577 para 240. Thus, even the possibility that services may be provided to citizens of or persons established in other Member States would suffice. In the judgment, the Court did not even dwell on the issue. It proceeded to examine the legality of the measures at hand in light of Article 49, finding them justified under the Treaty exceptions.

69 Joined cases 286/82 and 26/83 Graziana Luisi and Giuseppe Carbone v Ministero del Tesoro [1984] ECR 377 para 16.

70 Ritter (n 38) 693.

${ }^{71}$ Case C-184/99 Rudy Grzelczyk v Centre public d'aide sociale d'Ottignies-Louvain-laNeuve [2001] ECR I-6193 para 31.

72 Art 18 (1) of EC Treaty.

73 Shuibhne (n 7) 757. See also Tryfonidou (n 3) 61-62. 
The Court has, however, been less than responsive to such claims. In Uecker and Jacquet, it held that EU citizenship was not meant to 'extend the material scope of the Treaty to internal situations which have no link with Community law'. ${ }^{74}$ Admittedly, EU citizenship has made it easier for the Court to uphold some actions of private parties against their own Member State, either because they were penalised because they exercised free movement rights or because they were deterred from doing so. ${ }^{75}$ However, the cross-border requirement is still present.

The latest statements of the internal situation rule in citizenship cases came in French community and Walloon government vs Flemish government and Metock. ${ }^{76}$ In both cases, it was reiterated that EU citizenship cannot affect the scope of the Treaty in relation to internal situations. Therefore, citizenship does not in itself change the interpretation as far as internal situations are concerned. ${ }^{77}$

\subsection{A step further - cross-border implications of restrictive activities}

\subsubsection{Free movement of goods}

As we have seen, some judgments in the area of free movement of persons have found a cross-border element with relative ease. Case law on the free movement of goods goes a step further by focusing on general or potential cross-border implications of restrictive measures rather than the occurrence or possibility of movement in a specific case.

On the face of it, Treaty rules on the free movement of goods seem to have a clear scope of application. Unlike in free movement of persons, for example, EC Treaty provisions in this area are linked to trade between Member States, not within the internal market generally. ${ }^{78}$ Nevertheless, the Court has stretched the cross-border requirement in this context as well. The criteria which were applied, however, were rather different.

\footnotetext{
74 Joined cases C-64/96 and C-65/96 Land Nordrhein-Westfalen $v$ Kari Uecker and Vera Jacquet $v$ Land Nordrhein-Westfalen [1997] ECR I-3171 para 23.

75 Morgan (n 39) para 26.

76 Metock (n 4) and C-212/06 (n 17).

77 What it might achieve, however, is to affect the problem of reverse discrimination. Although the Court explicitly rejected the notion that reverse discrimination can be addressed at the EU level, it did point out, in a rather offhand way, that the European Convention on Human Rights could be relevant in such cases. Time will tell whether the Court did so in order to open the door to a more ambitious future holding on reverse discrimination.

78 Thus they state: "prohibition between Member States of customs duties on imports and exports and of all charges having equivalent effect' (art $23 \mathrm{EC}$, similarly in art $25 \mathrm{EC}$, emphasis added); 'quantitative restrictions on imports and all measures having equivalent effect shall be prohibited between Member States' (art 28 EC, emphasis added; the same language is in art $29 \mathrm{EC}$ with regard to exports).
} 
In its case law, the Court started by refusing to extend the protection of rules relating to the free movement of goods to internal situations, such as domestically produced goods (Mathot). ${ }^{79}$ In Anomar, the Court clarified this point, saying that trade-restrictive legislation "may generally fall within the scope of the provisions on the fundamental freedoms established by the Treaty only to the extent that it applies to situations related to intra-Community trade'.80

This case law has been loosened in two directions: first, in cases where there are obstacles to the movement of goods within a Member State, such as regional tariffs; second, the Court has been willing to apply the Treaty even to clearly internal situations when the legislation at issue was, in itself and in the abstract, contrary to EC law.

\subsubsection{Regional frontiers and intrastate obstacles}

The first line of cases, in particular Simitzi, Lancry and Carbonati Apuani, ${ }^{81}$ dealt with obstacles to the movement of goods within a single Member State. In these cases, the Court explicitly extended the scope of Treaty rules on pecuniary restrictions (Articles 23 and 25 EC) from crossborder trade to intra-Community trade in general:

Since the very principle of a customs union covers all trade in goods, as provided for by Article 9 of the Treaty [now Article 23 EC], it requires the free movement of goods generally, as opposed to interState trade alone, to be ensured within the Union. ${ }^{82}$

\footnotetext{
79 Case 98/86 Criminal proceedings against Arthur Mathot [1987] ECR 809 paras 7-8.

80 Case C-6/01 Associação Nacional de Operadores de Máquinas Recreativas (Anomar) and Others $v$ Estado português [2003] ECR I-8621 para 39. The Court left some room for confusion by pointing out that the national legislation at issue can be applied both to nationals of other Member States and of the Member State concerned. This would suggest that the nationality (or place of establishment) of the parties is decisive, rather than the cross-border
} movement of goods. See $\mathrm{s} 1.3$.

81 Joined cases C-485/93 and C-486/93 Maria Simitzi $v$ Dimos Kos [1995] ECR I-2655; Joined cases C-363/93, C-407/93, C-408/93, C-409/93, C-410/93 and C-411/93 René Lancry SA v Direction Générale des Souanes and Société Dindar Confort, Christian Ah-Son, Paul Chevassus-Marche, Société Conforéunion and Société Dindar Autos v Conseil Régional de la Réunion and Direction Régionale des Douanes de la Réunion [1994] ECR I-3957; Case C-72/03 Carbonati Apuani Srl v Comune di Carrara [2004] ECR I-8027.

82 Lancry (n 81) para 29. A somewhat dubious justification for a similar holding in Carbonati Apuani (n 81) is: 'If Articles $23 \mathrm{EC}$ and $25 \mathrm{EC}$ make express reference only to trade between Member States, that is because the framers of the Treaty took it for granted that there were no charges exhibiting the features of a customs duty in existence within the Member States' (para 22). As pointed out in P Oliver, 'Some Further Reflections on the Scope of Articles 28-30 (Ex 30-36) EC' (1999) 36 CML Rev 783, 785, this makes little sense, if for no other reason than the duty charged in Lancry existed for years before the signing of the first Treaties. 
Thus, the Treaty also applies to cases confined to one Member State whenever there is an obstacle to the movement of goods within a Member State. ${ }^{83}$

The Lancry holding was further developed in Jersey Potatoes, ${ }^{84}$ which extended the same principle to Article $29 \mathrm{EC}$, ie to non-pecuniary restrictions on exports. At issue were exports of potatoes from Jersey, a British Crown dependency, to the UK. However, for the purposes of the judgment, Jersey and the UK had to be treated as a single Member State. Thus, the 'exports' were, as a matter of law, intrastate movement of goods. Nevertheless, the situation was not held to be purely internal. ${ }^{85}$

This extension of the Treaty rules on free movement of goods to obstacles to intrastate trade can be explained in several ways. First, a measure might in practice also be applied to goods being exported to other Member States. In such a case, it is clear that there is no internal situation. Second, it could be practically difficult to tell the difference between goods in domestic trade and goods which are being imported or exported. ${ }^{86}$ Thus, removing the internal situation rule helps us avoid false negatives.

Thirdly, and most interestingly, duties on goods shipped from one region of a Member State to another have to be removed, since 'the customs union necessarily implies that the free movement of goods should be ensured ... within the customs union' ${ }^{87}$ This justification is conceptual in nature, and not related to any technical arguments on policing trade in goods. As argued by AG Sharpston in French community and Walloon government vs Flemish government, this argument could be extended (at least) to all cases of regional frontiers or other intrastate obstacles to free movement, not only to the free movement of goods. ${ }^{88}$ The Court has not, however, followed the Advocate General in this respect, considering Flan-

\footnotetext{
83 This was qualified by invoking Article 14(2) EC which defines the internal market as 'an area without internal frontiers', Carbonati Apuani (n 81) para 23.

84 Case C-293/02 Jersey Produce Marketing Organisation Ltd $v$ States of Jersey and Jersey Potato Export Marketing Board [2005] ECR I-9543. See also Tryfonidou, 'Case C-293/02, Jersey Produce Marketing Organisation Ltd v States of Jersey and Jersey Potato Export Marketing Board, Judgment of the Court (Grand Chamber) of 8 November 2005, not yet reported, case note' (2006) 43 CML Rev 1723, 1738-9, who argues that Jersey Potatoes does not in fact extend the application of Article 29 EC to goods travelling from Jersey to the UK.

85 Case C-293/02 (n 84) para 76. AG Léger in the same case argued the opposite quite strongly. See his opinion in para 107 and those that follow.

86 Oliver (n 82) 785.

87 Case C-30/01 Commission v UK [2003] ECR I-9481 paras 52-53. Therefore, Tryfonidou argues, the case should be understood in light of its specific facts.

88 AG Sharpston in C-212/06 (n 17) para 129.
} 
ders' refusal to grant social security benefits to workers residing in the French Community to be an internal situation.

\subsubsection{Pistre and restrictive domestic regulations}

Article 28 EC's prohibition of non-pecuniary restrictions on imports is where the provisions on the free movement of goods interface most strongly with the domestic, non-trade, policy of Member States. Internal situations in the context of Article 28 have been dealt with in a separate body of case law.

This second line of case law weakening the role of 'internal' situations in free movement of goods law stems from Pistre. ${ }^{89}$ At issue in this case was French legislation reserving the use of the word "mountain product' to agricultural products made in a certain way and in certain regions within France. It applied both to domestic and imported products, but imported products could never fulfil the criterion. Thus, the legislation was directly discriminatory and could have been easily challenged by any importer. The applicants, however, were domestic producers. What was at stake was an internal situation, though the challenged national legislation would also clearly be considered a restriction of free movement of goods in a cross-border case.

The Court's solution was to explicitly hold Article 28 applicable because the national provision 'may also have effects on the free movement of goods between Member States', even if all the facts of the 'specific case before the national court are confined to a single Member State'. ${ }^{90}$ The Court focused on the cross-border effects of the restrictive legislation rather than the cross-border elements of the facts.

This case could be seen as simply pronouncing, in the abstract, whether certain kinds of national legislation could withstand the scrutiny of Article 28, and then leaving it to the national court to decide whether this fact could be pleaded in a purely internal case. The distinction between external and internal cases is, however, never clearly made.

89 Joined cases C-321/94, C-322/94, C-323/94 and C-324/94 Criminal proceedings against Jacques Pistre (C-321/94), Michèle Barthes (C-322/94), Yves Milhau (C-323/94) and Didier Oberti (C-324/94) [1997] ECR I-2343.

$90 \quad$ Pistre (n 89) para 44. Oliver (n 82) 787-788 argues on the other hand that Pistre should apply only to non-internal situations as a matter of EC law. See however Case C-379/98, PreussenElektra AG v Schhleswag AG, in the presence of Windpark Reußenköge III GmbH and Land Schleswig-Holstein [2001] ECR I-2099 paras 69-70, where arguably the Court repeated the approach in Pistre. 
As argued by Tryfonidou, ${ }^{91}$ Pistre indeed removes the problem of arbitrariness in the application of internal market rules. By focusing on the restrictive legislation itself, rather than the facts to which the legislation was applied, it accomplished two things: it got rid of a potentially restrictive piece of legislation, and it (potentially) caught internal cases as well, thus removing the reverse discrimination problem. But we could easily imagine a case where this approach would not help domestic producers. What if France adopted the identical legislation as in Pistre, but provided that all imported goods, unlike goods produced in other regions within France, could freely use the designation 'mountain products' with no formalities? This would be directly discriminatory against domestic producers. But is there room in the Court's present case law to condemn this legislation under the Treaty?

This hypothetical case reveals a paradox. If they want to treat internal situations independently from EC law requirements, Member States are better off discriminating against them directly and explicitly, rather than adopting the same general rule for both external and internal situations. As long as internal situations are defined in a nuanced way so as to avoid any cross-border implications, it would not be possible to say that the legislation as such can potentially affect imports. If faced with such a case, it seems that the ECJ would be left with no option other than to tackle the problem of reverse discrimination directly, which at this point it does not seem prepared to do.

Pistre might be seen as an outlier, since the case law normally decides whether cases are internal on the basis of their specific facts. However, the approach gives food for thought. If the nature of the legislation, measure or activity challenged before the courts is such that it has crossborder ramifications, could that not suffice to supply a cross-border element? As it turns out, there are at least two other areas where something similar holds: competition law and public procurement law.

\subsubsection{Examples to follow? - competition law and public procurement}

EC competition and public procurement law are examples of more substantive approaches to regulating competition within the internal market. Similarly to Pistre, in these areas the Court focuses on the cross-border effects of the disputed measure or activity in general, rather than on the cross-border elements in the case at hand. Such an approach is more in line with the goal of filtering activities or measures which substantially

91 A Tryfonidou, 'The outer limits of Article 28 EC: Purely internal situations and the development of the Court's approach through the years', available at <http://ssrn.com/abstract $=1029248>13-15$. 
affect intra-Community trade and competition, and it also avoids many cases of reverse discrimination.

In both areas, the Court could conceivably apply the internal situation rule. Public procurement law is a specific application of free movement rules and the internal situation argument has indeed appeared in the case law. In competition law, the 'trade effects' test fulfils a similar role. However, the Court's approach is radically different from standard free movement cases.

\subsubsection{Competition law}

Provisions of the EC Treaty on anti-competitive agreements (Article $81 \mathrm{EC}$ ), abuses of a dominant position (Article $82 \mathrm{EC}$ ) and state aids (Article $87 \mathrm{EC}$ ) extend to all anti-competitive behaviour, even that which does not involve an express cross-border element, as long as it affects trade between Member States. ${ }^{92}$ Similarly to the internal situation rule, the trade effects requirement is meant to protect Member State competences, as it 'incorporates the notion of subsidiarity'. ${ }^{93}$ Consequently, just as in 'purely internal' cases within the context of free movement provisions, some anti-competitive behaviour passes under the radar of Community law, and can be dealt with solely on the basis of the law of the Member State concerned.

Crucially, however, when examining whether anti-competitive activity is able to affect the internal market, what counts are not its crossborder characteristics, but only its general ability to have an impact on competition. It is the size of the fish that is important, not how far it has travelled within the pond. Thus, if a company is based, has offices, employs workers, makes contracts, sells products, and in all other respects does business in one Member State only, it could still be found guilty of a violation of EC competition law, as long as a 'substantial part' of the internal market is affected. This will be particularly true if the effects of anti-competitive conduct are felt outside of the Member State, either by influencing the pattern of interstate trade or by interfering with the structure of competition within the internal market. ${ }^{94}$ Thus, the Court held in

\footnotetext{
92 To use as an example the text of Article 82 EC: "Any abuse by one or more undertakings of a dominant position within the common market or in a substantial part of it shall be prohibited as incompatible with the common market in so far as it may affect trade between Member States.' For the Court's understanding, see Case 322/81 NV Nederlandsche Banden Industrie Michelin v Commission of the European Communities [1983] ECR 3461 paras 102-105. See also Maduro (n 3) in n 28.

93 Jones and Sufrin, EC Competition Law: Text, Cases and Materials (2 ${ }^{\text {nd }}$ edn Oxford 1987) 89.

94 Jones and Sufrin (n 93) 287.
} 
Hugin that 'Community law covers any agreement or any practice which is capable of constituting a threat to freedom of trade between Member States in a manner which might harm the attainment of the objectives of a single market between the Member States.'95

Apart from the fact that cross-border elements are not discussed as such, there are two other differences between the Court's case law on free movement provisions and competition provisions. First, the inquiry here focuses directly on the abuse or restriction of Community law rather than on the parties or other elements of the case. In the free movement context, this would be equivalent to examining restrictive national legislation regardless of the parties' cross-border movement. ${ }^{96}$ Second, the requirement of trade effects in competition law is easily satisfied, since a 'direct or indirect, actual or potential' influence on the pattern of interstate trade suffices. ${ }^{97}$

It is not completely clear why the 'trade effects' test and the internal situation rule should be interpreted so differently. While, broadly speaking, the scope of competition rules is not identical to that of free movement rules, ${ }^{98}$ in this specific respect it is hard to justify the differences. In both areas, the EU's policy is essentially market-based integration. Notions of trade and competition within the internal market are interlinked: cross-border trade is an important consideration in competition law, just as cross-border competition underlies the interpretation of free movement rules. ${ }^{99}$

95 Case 22/78 Hugin Kassaregister $A B$ and Hugin Cash Registers Ltd $v$ Commission [1979] ECR 1869 para 17. See also the Commission's Guidelines on the Effect of Trade Concept Contained in Articles 81 and 82 of the Treaty [2004] OJ (C101/81).

96 See $\mathrm{s}$ 2.2.1.2.

97 Case 56/65 Société Technique Minière (LTM) v Maschinenbau Ulm GmbH (MBU) [1966] ECR 235 para 7. It has also been held (Case 246/86 SC Belasco and others $v$ Commission of the European Communities [1989] ECR 2117 paras 33-34) that a cartel limited to the marketing of products in only one Member State affects interstate trade. However, the opposite was true in Joined cases C-215/96 and C-216/96 Carlo Bagnasco and Others $v$ Banca Popolare di Novara soc coop arl (BNP) (C-215/96) and Cassa di Risparmio di Genova e Imperia SpA (Carige) (C-216/96) [1999] ECR I-135 paras 51-52. See Jones and Sufrin (n 93) 174.

98 It was held, for example, that activities excluded from the scope of free movement provisions may still fall within the scope of competition rules - Case C-519/04 P David MecaMedina and Igor Majcen $v$ Commission [2006] ECR I-6991 para 31.

99 Thus, Article 2 EC states: The Community shall have as its task, by establishing a common market and an economic and monetary union and by implementing common policies or activities referred to in Articles 3 and 4, to promote throughout the Community ... a high degree of competitiveness and convergence of economic performance'. 


\subsubsection{Public procurement law}

Public procurement law is an even more striking example of inconsistency in the scope of application of the provisions of Community law. It is much harder to distinguish from 'normal' free movement cases than competition law, because public procurement in EC law is simply a specific application of Articles 49 (free provision of services) and 43 (freedom of establishment) EC. To explain the inconsistencies here, let us take up again the example of a company confined to a single Member State in all its activities.

If that fictional company wins a public tender within its Member State, and the contract notice was not published in the EU Official Journal as required by Directive $2004 / 18,{ }^{100}$ there might be a legal challenge. Because the tender is not publicised on an EU-wide basis, however, the challenger is likely to be a domestic competitor, possibly making the case an internal one. Nevertheless, the Directive will almost certainly be held to apply, even if no foreign competitor complains, as long as the contract amount exceeds the threshold values laid down by the Directive. ${ }^{101}$ In fact, even if the contract falls below the thresholds and the Directive cannot be applied, the contract award is still subject to Articles 49 and 43 $\mathrm{EC}$, as well as the general principles of non-discrimination and transparency. ${ }^{102}$ This holds true even if all the facts are confined to one Member State.

It is clear why this kind of thinking makes sense. If the internal situation rule was applied, Member States could escape liability by doing exactly what the public procurement directives are meant to restrain - withholding the EU-wide publication of tenders. By making sure that only domestic companies can participate, they would be artificially keeping all situations internal, and thus outside the scope of Community law.

For these reasons, it might seem surprising that the internal situation argument has appeared in the Court's case law even once. In RI.SAN, an Italian company which previously ran a local waste management service challenged a municipality's decision to form a new company which would run these operations in the future. The Court refused to apply Articles (now) 43 and 49 EC, stating that RI.SAN 'has its seat in Italy and does not operate on the Italian market in reliance on freedom of estab-

\footnotetext{
100 Directive 2004/18/EC of the European Parliament and of the Council [2004] OJ L134/23, 35.

101 Directive 2004/18/EC (n 100) art 7.

102 Case C-458/03 Parking Brixen GmbH $v$ Gemeinde Brixen and Stadtwerke Brixen AG [2005] ECR I-8585 para 46.
} 
lishment or freedom to provide services'. ${ }^{103}$ Therefore all the facts were confined to Italy and the discussion stopped.

A consistent application of such a holding could have made EC public procurement law much less effective. Presumably, this is why it did not take long to see a different approach from the Court in Coname, another Italian case, and one with almost identical facts. To answer the question of whether the contract award at issue was contrary to Articles 43 and $49 \mathrm{EC}$, the Court relied on potential, or implied, competition:

... in so far as the concession in question may also be of interest to an undertaking located in a Member State other than the Member State of the Comune di Cingia de' Botti, the award, in the absence of any transparency, of that concession to an undertaking located in the latter Member State amounts to a difference in treatment to the detriment of the undertaking located in the other Member State. ${ }^{104}$

In other words, because of hypothetical discrimination against an imagined competitor, the applicant was able to obtain a remedy. ${ }^{105}$

Building on this judgment, the Court rejected the internal situation argument even more forcefully in Parking Brixen. ${ }^{106}$ In the absence of advertisements for the competition, the Court stated 'there is discrimination, at least potentially, against undertakings of the other Member States which are prevented from making use of the freedom to provide services and of the freedom of establishment'. ${ }^{107}$

103 Case C-108/98 RI.SAN. Srl v Comune di Ischia, Italia Lavoro SpA and Ischia Ambiente SpA [1999] ECR I-05219 paras 21-22. See also Andrea Biondi, 'In and Out of the Internal Market: Recent Developments on the Principle of Free Movement' (1999/2000) 19 Ybk Eur L 469, 484.

104 Case C-231/03 Consorzio Aziende Metano (Coname) v Comune di Cingia de' Botti [2005] ECR I-7287 para 17.

105 It is interesting that Advocate General Stix-Hackl was more cautious. While noting the special nature of public procurement, pointing to the problem of potential competition and thus putting into question the holding in RI.SAN, she focused on the ability of the Court to answer the national court's question even if the situation is purely internal. Opinion of AG Stix-Hackl, Coname (n 104) para 21.

106 Parking Brixen (n 102). In neither of these cases did the Court expressly mention its holding in RI.SAN, nor distinguish the cases in any way.

107 Parking Brixen (n 102) para 55. The Court is able to solve the internal situation conundrum by relying on hypothetical competitors from other Member States. An interesting question is, however, whether domestic companies could be directly protected by arguing that non-transparency adversely affects their efforts to compete across the internal market. The assumption that they are favoured by non-transparent public procurement procedures simply because they are established in the same Member State as the contracting authority is rather unrealistic. Thus, in public procurement, the Court is closer to economic reality simply because of its use of a more extensive proxy, not because of a particularly wide understanding of the fundamental freedoms and cross-border competition. In any event, after Coname and Parking Brixen, it seems that the only way for a contracting authority to escape 
What is the relevance of Coname and Parking Brixen for other aspects of free movement law? While it seems very specific, the outcome in public procurement cases is, again, similar to Pistre. Instead of focusing on the parties of the specific case and their cross-border activities (or lack thereof), the Court looked directly at the activity or restriction at issue. In Pistre, the restriction consisted in discriminatory legislation, and in Coname and Parking Brixen in the award of a public contract. ${ }^{108}$

These cases also share a common feature with the competition law approach outlined above. The focus is on the restriction that is being challenged: legislation and measures of the Member States, or private anti-competitive conduct. In competition law, this is achieved on a more systematic level, while public procurement uses the proxy of hypothetical cross-border competition. The Court's analysis moves in a similar direction. This does not fit well with the Court's usual approach to internal situations, which is to look at the facts of the case at hand and search for links to cross-border movement.

The examples of public procurement and competition law, along with Pistre, provide hints of a possible different solution to the internal situation puzzle. Before addressing this solution, however, it is important to consider a separate line of case law in which the Court has been willing to give an interpretation of Community law, regardless of the cross-border implications or elements, through the back door of the legal systems of the Member States.

\subsection{Answering the question - a procedural remedy in the context of Article 234 EC?}

Even in purely internal cases, the Court has been willing to give national courts guidance on points of Community law within a preliminary reference procedure (Article 234 EC). Again, its approach has been less than strict: even the slightest justification has sufficed for the Court to give an interpretation of EC provisions.

\footnotetext{
liability for non-transparent award procedures under EC law is to show that the contract was of 'very modest economic interest', or that there is some other special circumstance, so that undertakings from other Member States would have no interest in it (Coname n 105 para 20).

108 One difference is that in public procurement law, non-discrimination is the mandate of contracting authorities. It would be difficult to partition their task in a way which would allow them to discriminate against domestic companies without potentially affecting companies from other Member States. It would be interesting, however, to see the outcome of a case in which a Member State, for example, expressly reserved certain remedies only to companies established in other Member States to the detriment of their own companies. Would this fall under the scope of the Treaty and/or the public procurement directives?
} 
There are two lines of case law on which this is based. The first, starting with Dzodzi, ${ }^{109}$ allows the Court to provide an answer even in cases where EU law cannot be applied, as long as the relevant national legislation refers to EU law in some way (eg by stating that the law is intended to implement an EU directive). ${ }^{110}$ This reference does not have to be explicit and its strength can vary. It is enough that the two sets of legislation 'adopt the same solutions'. ${ }^{111}$ Because national law incorporates the solutions of Community law, it makes sense to give an interpretation of Community law to the national court.

The second relevant line of case law, starting with Guimont, ${ }^{112}$ is specifically linked to reverse discrimination. The Court assumes jurisdiction to give an answer if the national court has a duty under its own law to prevent reverse discrimination. Thus, if the national court is bound to treat internal situations and those falling under the scope of Community law equally, the Court should be able to explain what would happen if the case was governed by Community law. In Guimont and Cipolla, ${ }^{113}$ however, the Court approached this quite broadly, giving an answer without even inquiring whether such a provision exists at all in the law of the Member State concerned.

It is hard not to agree with criticisms ${ }^{114}$ that this approach goes against the normal logic of the preliminary reference procedure. If the

109 Joined cases C-297/88 and C-197/89 Massam Dzodzi v Belgium [1990] ECR I-3763 para 36. Other cases include Case C-28/95 A Leur-Bloem v Inspecteur der Belastingdienst/ Ondernemingen Amsterdam 2 [1997] ECR I-4161 para 25; Case C-130/95 Bernd Giloy v Hauptzollamt Frankfurt am Main-Ost [1997] ECR I-4291 para 21; and Case C-1/99 Kofisa Italia Srl v Ministero delle Finanze, Servizio della Riscossione dei Tributi - Concessione Provincia di Genova - San Paolo Riscossioni Genova SpA [2001] ECR I-207 para 32.

110 The same is true in competition law. See Case C-217/05 Confederación Española de Empresarios de Estaciones de Servicio v Compañía Española de Petróleos SA [2006] ECR I-11987 para 20.

111 See also Case C-3/04 Poseidon Chartering BV $v$ Marianne Zeeschip VOF and Others [2006] ECR I-2505 para 16.

112 Case C-448/9 Criminal proceedings against Jean-Pierre Guimont [2000] ECR I-10663 paras 22-23.

113 In Joined cases C-94/04 and C-202/04 Federico Cipolla v Rosaria Fazari, née Portolese (C-94/04) and Stefano Macrino and Claudia Capoparte v Roberto Meloni (C-202/04) [2006] ECR I-11421, the parties were Italian lawyers in dispute with Italian clients about legal fees for legal services rendered completely within Italy regarding Italian cases. However, the ECJ held that the national legislation - subject to the national court's finding of proportionality - could be contrary to Article 49.

114 Ritter (n 38) 698-702. AG Jacobs in his Opinion in Case C-306/99 Banque internationale pour l'Afrique occidentale SA (BIAO) v Finanzamt für Großunternehmen in Hamburg [2003] ECR I-1, similarly stated: 'it is difficult to see how it serves the purpose of Article $234 \mathrm{EC}$, which confers jurisdiction on the Court to give preliminary rulings concerning the validity and interpretation of acts of the institutions of the Community, for the Court to interpret Community provisions in so far as they are taken over by national legislation and 
purpose is simply to provide a persuasive opinion that the national court may or may not follow, then such an interpretation could be given in all cases coming before the Court. What is the significance of the fact that domestic law might prohibit reverse discrimination, or even of the fact that EC law was invoked in implementing measures?

This does not exhaust the problems of the Guimont approach. It is also difficult to distinguish these cases from Pistre, or the public procurement cases. In each of these cases, Member States adopt potentially restrictive legislation or measures which could be examined under free movement rules. In each of these cases, the parties and other elements of the dispute seem confined to a single Member State.

Yet, the outcomes are wildly different. In Pistre and (with a slightly different justification) Parking Brixen, the Court goes for a straightforward application of the Treaty. In Guimont and Cipolla, the Court holds the specific cases to be outside the scope of EC provisions but gives a non-binding interpretation anyway. As the case law stands currently, it is difficult to predict which of these approaches the Court will use in any given case.

\section{A more substantive link with the internal market?}

As indicated by several examples (section 2), there are two basic problems with the Court's case law on internal situations. First, it has been inconsistent across various provisions of the Treaty and secondary law. ${ }^{115}$ Moreover, the doctrine is too often focused on formalistic and factually contingent links to free movement, potentially neglecting to address cases where the dispute deals with serious impediments to free movement. Reverse discrimination is the most obvious, but not the only unwanted consequence. An overly strong rule on internal situations can also allow many restrictive measures to go unchecked, simply because of a formalistic obstacle which, as we have seen, ${ }^{116}$ does not do much to protect Member State competences.

applied to a situation manifestly outside the scope of those provisions and hence beyond their intended reach' (para 59).

115 Much has been written on the convergence between the four freedoms and the need for a similar standard of review across these freedoms (goods, persons, services, capital). See eg L Woods, Free Movement of Goods and Services within the European Community (Ashgate, 2004) 293-297 and the works cited therein. Certainly, there are differences in the way Treaty provisions dealing with free movement are framed and applied, not to mention secondary law adopted on their basis. However, none of these differences speaks in favour of a fundamentally different approach to the treatment of internal situations.

116 See $\mathrm{s} 1.3$. 
I do not suggest that this problem can go away at the stroke of a pen, or that the internal situation rule should be abolished. However, the definition of internal situations could be made more consistent and more substantive. In suggesting such an approach, I start from two points.

First, the internal situation rule is one of several instruments of judicial restraint meant to protect the regulatory autonomy of Member States from excessive interventions based on EC internal market rules. Second, as argued above in section 1.2.1.3, the rule is not an overarching principle of Community law, but is relevant only for internal market law, more specifically, for provisions on free movement. These two propositions enable us to view the internal situation rule mainly on the basis of two benchmarks: protection of Member State competences and internal market regulation.

One way to address the problems outlined above would be to tackle the problem of reverse discrimination directly, perhaps with the aid of the provisions on EU citizenship or fundamental rights. However, this solution has not been the focus of this article. For present purposes, it suffices to say that the Court has not been receptive to this idea, and has rejected it again in quite recent cases such as Metock and French community and Walloon government $v$ Flemish government. ${ }^{117}$

Another route could be to attempt to pull as many cases as possible into the net of Community law by thinking creatively when looking for a cross-border element in their facts. ${ }^{118}$ If the parties are merely deterred from exercising their free movement rights, ${ }^{119}$ or if they are treated less favourably because of previous or current movement, the cross-border requirement could be fulfilled. Cases where the European Court is willing to answer the national court's questions even though the case is admittedly internal, acting under the assumption that there can be a solution for reverse discrimination under domestic law, can be seen in this light as well.

This approach would extend Community law protection to a wider range of situations, but would still not solve the problem of the unpredictability of what would be deemed internal. This is all the more so because some of the inroads the Court was willing to make are limited to specific subject matter, even though they could be applied across the board. For example, regional frontiers could conceivably be relevant not only for the free movement of goods (as in Lancry) but also other market freedoms (such as in French community and Walloon government $v$ Flemish government).

\footnotetext{
117 Metock (n 4) and C-212/06 (n 4).

118 See s 2.1.1.

119 See s 2.1.2.
} 
In addition, in this approach, cases where the restriction at issue truly affects the internal market can still pass under the radar because of the lack of any cross-border elements, whereas even tenuous cross-border elements could justify a case with little actual impact on free movement. ${ }^{120}$

These problems indicate that the definition of internal situations should be more substantive, and more attuned to the values which are actually at stake: protection of Member State competences and effective regulation of the internal market. Pistre, competition law and public procurement law can serve as an inspiration for an approach which would serve these interests better.

In this approach, the cross-border implications of the law, administrative measure or private activity challenged as a possible breach of Community provisions would also be taken into account when deciding whether a case was purely internal. If it is clear that the measure is, at least in some circumstances, contrary to EC law (specifically, to the free movement provisions of the EC Treaty or secondary law), the principle of supremacy requires it to be put aside by the national court. The specific facts of the case at hand should not be decisive, as long as the applicant is truly affected by the illegal measure. This would enable a number of trade-restrictive measures to be examined under Community law, even if there are no other factual cross-border elements. Thus, the internal market could function more effectively, and a number of cases of reverse discrimination would be addressed.

This approach would require a substantial change of direction in the case law. In addition, it might seem to subject many more situations to Community law. However, it should be pointed out that this interpretation only applies to measures which could, in the abstract, affect free movement. This means that Member States would still be able to remove internal situations from the scope of EU law, as long as they do so explicitly and clearly. For example, they could align their legislation with the requirements of EC law but restrict the application of the legislation to cross-border situations (however many difficulties there may be in making this distinction, see section 1.3).

Thus, this approach would still enable the Court to safeguard Member State competences by declaring Community law inapplicable where neither the facts of the case at hand nor the restriction being challenged have cross-border implications. Moreover, even if a measure can be challenged, there are still a number of mechanisms of judicial restraint which would enable the Court to abstain from passing judgment and leave the

120 Opinion of AG Sharpston in C-212/06 (n 17) para 91. See also Tryfonidou (n 91) 6-7. 
matter to the Member State concerned. Most notably, as it has done before, ${ }^{121}$ it could hold the measures to be 'too uncertain and indirect' to affect free movement. This would be akin to a de minimis test (and not unlike the 'trade effects' test in competition law). Some cases where movement does take place should be left to national law because of their limited significance or slight cross-border implications. In addition, the Keck jurisprudence gave the Court the necessary ammunition to remove from scrutiny various non-discriminatory measures which do not affect the pattern of trade between Member States. ${ }^{122}$ All this makes a strict, facts-based version of the internal situation rule not only ill-suited, but also unnecessary for the preservation of Member State competences.

\section{Conclusion}

Although there are good reasons for its existence, the application of the internal situation rule has been fraught with difficulties. What I have tried to show is that the rule should, first of all, be construed narrowly. It is only relevant for the application of those provisions of EC or EU law that require some sort of movement or cross-border element. Therefore, it should not be thought of as a general principle of Community law.

The rule does not perform well in light of either of the two competing interests: preservation of Member State competences or effective regulation of the internal market. It does not make it easier for Member States to regulate independently, except if they make detailed distinctions between cases where movement is or is not present. Second, the way in which the rule is applied by the Court has been inconsistent across various provisions of EC internal market law and disconnected from the substance of cross-border trade and movement, focusing instead on contingent and often irrelevant factors related to the specific case of the applicants.

This is why I propose the extension of the approach in Pistre, inspired also by the case law on public procurement and by the trade effects requirement from competition law. This approach would apply Community law to a number of cases where the effectiveness of the internal market is substantially affected. It would allow Member States to regulate truly internal situations independently - but without inflicting collateral damage on freedom of movement.

121 Among others, see Case C-69/88 H Krantz GmbH \& Co v Ontvanger der Directe Belastingen and Netherlands State [1990] ECR I-583 para 11; Case C-44/98 BASF AG v Präsident des Deutschen Patentamts [1999] ECR I-6269 para 16; and the Order in Case C-431/01 Philippe Mertens $v$ Belgium [2002] ECR I-7073 para 34.

122 See n 15. 